\title{
Viral antichemokines: from pathogenesis to drug discovery
}

\author{
Philip M. Murphy
}

Laboratory of Host Defenses, National Institute of Allergy and Infectious Diseases, Building 10, Room 11N113, National Institutes of Health, Bethesda, Maryland 20892, USA.

Phone: (301) 496-8616; Fax: (301) 402-4369; E-mail: pmm@nih.gov.

In a recent JCI Commentary, Steven Kunkel reviewed the organization of the chemokine system and its important role in the development, differentiation, and deployment of mammalian leukocytes (1). The system is massive (about 50 ligands and 18 receptors are known), reflecting the complexity of its major client, the immune system. Now in this issue of the JCI, Liu and colleagues remind us that an antichemokine system has evolved in viruses, presumably as a strategy to evade the immune system, and they provide the first glimpse of how antichemokines might be exploited clinically as "ready-made" anti-inflammatory drugs (2).

Antichemokines comprise a major group of virus-encoded chemokine modulators (Table 1) and consist of three subgroups based on structure and mechanism of action: (a) chemokine homologues that act as chemokine receptor antagonists (e.g., MC148R of Molluscum contagiosum virus [MCV]; ref. 3); (b) plasma membrane-expressed chemokine receptor homologues, which function as chemokine scavengers (e.g., US28 of human cytomegalovirus; ref. 4); and (c) three subtypes of secreted chemokine-binding proteins, which have unique structures and unknown ancestry but function as extracellular chemokine scavengers (examples include M3 of $\gamma$-herpesvirus $68[5,6]$ and various poxivirus proteins, including MT7 of myxoma, investigated by Liu et al. in this issue [2]). Three other groups of virus-encoded chemokine modulators have quite different functions. They include (a) chemokine receptor homologues, such as open reading frame 74 of
Kaposi's sarcoma-associated herpesvirus (7), which serves as a growth factor and angiogenic factor; (b) chemokine homologues that function as chemokine receptor agonists, including vMCK- 1 of murine cytomegalovirus, which promotes viral dissemination via monocytes (8); and (c) nonchemokine agonists and antagonists of chemokine receptors, encoded by the HIV genome.

Viral chemokine modulators, in turn, are part of a larger group of viral proteins with obvious homology to host proteins. These primarily include immunomodulatory, growth factor, and cell cycle control proteins (9). Interestingly, M-T7 is a hybrid. It has one domain homologous to the extracellular region of the IFN- $\gamma$ receptor, as well as a $\mathrm{COOH}$-terminal chemokine-binding domain. Chemokines bind $\mathrm{M}-\mathrm{T} 7$ via their $\mathrm{COOH}$-termi-

Table 1

Viral chemokine modulators

\begin{tabular}{|c|c|c|c|c|c|}
\hline Virus family & Virus & ORF & $\begin{array}{l}\text { Common } \\
\text { names }\end{array}$ & $\begin{array}{l}\text { Chemokine or } \\
\text { receptor class }\end{array}$ & Function \\
\hline \multirow[t]{6}{*}{$\gamma$-Herpesviridae } & H. saimiri & 74 & ECRF3 & $\mathrm{ELR}+\mathrm{CXCR}$ & Calcium flux in vitro \\
\hline & HHV8 (KSHV) & 74 & ORF 74 & & \\
\hline & & M3 & M3 & $\begin{array}{c}\text { Chemokine binding } \\
\text { protein }\end{array}$ & $\begin{array}{l}\mathrm{C}, \mathrm{CXC}, \mathrm{CC}, \mathrm{CX} 3 \mathrm{C} \\
\text { chemokine scavenger }\end{array}$ \\
\hline & & & KSHV GPCR & $\begin{array}{c}\text { CC/CXCR } \\
\text { (constitutively active) }\end{array}$ & $\begin{array}{l}\text { Oncogenic } \\
\text { Angiogenic }\end{array}$ \\
\hline & & K6 & VMIP-I & CC chemokine & $\begin{array}{c}\text { Angiogenic } \\
\text { CCR8 agonist }\end{array}$ \\
\hline & & K4 & vMIP-II & CC chemokine & $\begin{array}{c}\text { Angiogenic } \\
\text { HIV suppressive } \\
\text { Th2 chemoattractant } \\
\text { Antagonist at CCR1, CCR2, } \\
\text { CCR3, CCR5, CXCR4, and CCR8 }\end{array}$ \\
\hline \multirow[t]{5}{*}{$\beta$-Herpesviridae } & Human CMV & US28 & US28 & $\mathrm{CC} / \mathrm{C} \times 3 \mathrm{CR}$ & $\begin{array}{l}\text { Calcium flux } \\
\text { Chemokine }\end{array}$ \\
\hline & & & & & $\begin{array}{l}\text { Smooth muscle } \\
\text { cell chemokinesis }\end{array}$ \\
\hline & & & & & HIV coreceptor \\
\hline & & UL146 & $v C X C-1$ & CXC chemokine & $\begin{array}{l}\text { Neutrophil calcium } \\
\text { flux, chemotaxis, and } \\
\text { degranulation } \\
\text { CXCR2-specific }\end{array}$ \\
\hline & & UL147 & $v C X C-2$ & CXC chemokine & NA \\
\hline
\end{tabular}


Table 1 (continued)

\begin{tabular}{|c|c|c|c|c|c|}
\hline & Mouse CMV & $\mathrm{m} 131 / 129$ & $\begin{array}{c}\mathrm{m} 131 / 129 \\
\text { MCK-1/MCK-2 }\end{array}$ & (m & $\begin{array}{c}\text { Virulence factor } \\
\text { Blocks natural killer } \\
\text { and T-cell response to } \\
\text { MCMV in vivo; } \\
\text { also proinflammatory } \\
\text { early in infection. } \\
\text { Mutant virus } \rightarrow \text { reduced viremia } \\
\text { Calcium flux } \\
\text { (mouse peritoneal macrophages; } \\
\text { human CCR3 transfectants) }\end{array}$ \\
\hline & HHV6 & U12 & U12 & CCR & Calcium flux in vitro \\
\hline & & U83 & U83 & CC chemokine & THP-1 cell chemotaxis \\
\hline \multirow[t]{3}{*}{ Poxviridae } & $\begin{array}{c}\text { Molluscum contagiosum } \\
\text { virus (MCV) }\end{array}$ & MC148 & $\begin{array}{l}\text { MC148R } \\
\text { vMCC-1 }\end{array}$ & $\mathrm{m}$ & $\begin{array}{l}\text { Blocks neutrophil } \\
\text { monocyte, and T-cell chemotaxis } \\
\text { induced by multiple CC } \\
\text { and CXC chemokines } \\
\text { Antagonist at CCR2 and CCR8 } \\
\text { Blocks human hematopoietic } \\
\text { progenitor cell proliferation }\end{array}$ \\
\hline & Ortho- and leporipoxviruses & B29R (vaccinia) & $\begin{array}{c}\text { T1 } \\
\text { 35-kDa protein } \\
\text { vCCl } \\
\text { vCKBP } \\
\text { vCBP-I }\end{array}$ & $\begin{array}{l}\text { CC chemokine- } \\
\text { binding protein }\end{array}$ & $\begin{array}{c}\text { Broad spectrum } \\
\text { CC chemokine scavenger } \\
\text { Anti-inflammatory in context } \\
\text { of vaccinia infection and } \\
\text { allergic airway inflammation } \\
\text { in guinea pigs }\end{array}$ \\
\hline & Myxoma & $\mathrm{T7}$ & $\begin{array}{c}\text { T7 } \\
\text { vCBP-II }\end{array}$ & $\begin{array}{c}\text { C, CXC, and } \\
\text { CC chemokine-binding protein }\end{array}$ & $\begin{array}{l}\text { Broad spectrum chemokine } \\
\text { and IFN- } \gamma \text { scavenger } \\
\text { Virulence factor: } \\
\text { anti-inflammatory in context } \\
\text { of myxoma infection }\end{array}$ \\
\hline Lentiviridae & HIV & Tat & gp120 & $\begin{array}{l}\text { CC chemokine } \\
\text { mimic }\end{array}$ & $\begin{array}{c}\text { Monocyte chemoattractant: } \\
\text { CCR2, CCR3 agonist } \\
\text { HIV suppressive factor at CXCR4 } \\
\text { CCR8 antagonist } \\
\text { Chemotactic agonist at CCR5 } \\
\text { Neuronal apoptosis via CXCR4 }\end{array}$ \\
\hline
\end{tabular}

All molecules listed, except for the poxvirus chemokine-binding proteins and HIV Tat, have conserved sequences with cellular chemokines or chemokine receptors CCR, CC chemokine receptor; CXCR, CXC chemokine receptor; ELR+, subclass of neutrophil-targeted CXC chemokines; NA, not available; ORF, open reading frame; HHV, human herper virus, KSHV, Kaposi's sarcoma-associated herpervirus; CMV, cytomegalovirus; MCMV, mouse cytomegalovirus. See text and ref. 14 for primary citations.

nal glycosaminoglycan-binding (GAGbinding) domain (10). Fortuitously, MT7 binds only to the rabbit form of IFN$\gamma$, whereas for chemokines it crosses species barriers, thus permitting its use as a selective chemokine blocking agent in species other than rabbits.

Much of the rapid progress in this field can be attributed to major advances in viral genomics and to the advent of computer cloning. Examples continue to be found as additional viral genomes are sequenced and analyzed. However, in most cases it has been difficult to define relevant biological correlates, owing either to difficulty studying the virus (as in the case of $\mathrm{MCV}$, which has not been grown in culture) or to the absence of animal models for the viral disease. Nevertheless, the general notion that chemokines act in antiviral host defense has solid support from studies with knockout mice lacking the chemokine macrophage inflammatory protein-1 $\alpha$ (MIP-1 $\alpha$ ). These animals show decreased inflammatory responses to influenza A, Coxsackie B, and murine cytomegalovirus $(11,12)$. Thus it is tempting to speculate, for example, that the odd absence of inflammatory cells in pathologic lesions caused by MCV results from an antichemokine shield provided by secretion of its antichemokine MC148R (3). Myxoma virus, which causes a fatal systemic immunosuppressive disease known as myxomatosis in the European rabbit Oryctolagus cuniculus, is well suited to experimental analysis, and of all secreted myxoma gene products analyzed to date, deletion of M-T7 most profoundly attenuates virus virulence (ref. 13; G. McFadden, personal communication). However, whether this is due to blockade of IFN- $\gamma$, chemokines, both, or neither is still not clear.

Viral antichemokines typically have broad spectrum activity (e.g., M-T7 binds multiple CXC and CC chemokines, as well as the $\mathrm{C}$ chemokine lymphotactin), which suggests converse- 
ly that the host mounts a broad antiviral chemokine response. This is consistent with studies of chemokine expression in patients with immunologically mediated diseases, such as multiple sclerosis, rheumatoid arthritis, and psoriasis. Yet, counterintuitively, knockout or neutralization of just one chemokine or receptor in vivo markedly attenuates pathology in numerous and diverse animal models of inflammation (reviewed in ref. 14). While detailed studies of the spatial and temporal aspects of chemokine expression during the course of inflammatory challenge are needed to more fully interpret these results, these successes may justify developing antichemokine therapies for the clinic.

Recently several potent small molecule antagonists of specific chemokine receptors have been discovered, and more are on the way (14). Some of these were obtained "off the rack" as HIV entry blockers, after the discovery that the chemokine receptors CCR5 and CXCR4 play a major role in this process (15). Others were found by drug discovery efforts targeting specific chemokine receptors. Additional blocking strategies underway include development of humanized neutralizing antibodies to chemokines and chemokine receptors. Preclinical studies and disease indications, eagerly awaited for all of these compounds, are now available for MT7. As Liu et al. (2) report, a single intravenous injection of just $0.017 \mathrm{pg} / \mathrm{g}$ of M-T7 protein given to rats or rabbits immediately after balloon angioplasty attenuated atherosclerosis/restenosis injury, including reduction in both neointima formation and macrophage infiltration. Since M-T7 binds the chemokine monocyte chemoattractant protein-1 (MCP-1), the results fit well with recent reports of reduced pathology in atherosclerosis-prone mice when either MCP-1 or its receptor CCR2 is genetically disrupted $(16,17)$. Moreover, since M-T7 does not bind rat IFN$\gamma$, the effects in rats cannot be due to scavenging of that cytokine. Indirect arguments suggest that the effects are not mediated by IFN- $\gamma$ in the rabbit model either (2).

Whether the histological effects of MT7 in this model are really due to blockade of MCP-1 (or some other chemokine) is still unresolved. The authors show that M-T7 treatment is associated with reduced detection of MCP-1, MIP-1 $\alpha$, and RANTES antigen in the medial layer of the arterial wall after angioplasty injury in the rat model, but they are careful to point out that this effect could occur by several mechanisms, including antigen masking. Moreover, the maximal concentration that one might achieve in vivo from the $0.017 \mathrm{pg} / \mathrm{g}$ dose of M-T7, even assuming distribution to be restricted to the intravascular space, is much lower than the reported $\mathrm{K}_{\mathrm{d}}$ for chemokine binding. Finally, M-T7 could potentially bind to other extracellular regulators that contain GAG-binding domains, such as basic FGF (A. Lucas, personal communication). Despite these caveats about mechanism, the efficacy of M-T7 is quite striking and no toxicity was noted. Thus, restenosis injury may now be regarded as a disease indication for further clinical development of this compound. It remains to be seen whether M-T7 will provide a useful anti-inflammatory therapy for established inflammation or systemic disease. Timing of administration, bioavailability, pharmacokinetics, and antigenicity will pose bigger problems in those clinical settings than in the present experimental study.

The M-T7 results are similar to this group's previous reported results for SERP-1, a secreted serine proteinase inhibitor made by myxoma, in the same rat and rabbit models as well as in a rat aortic allograft model of transplant vasculopathy, and in a rabbit model of antigen-induced arthritis (18-20). These results persuaded the authors to launch a new biotechnology company, Viron Therapeutics Inc., London, Ontario, Canada, to explore the therapeutic potential of natural viral immunomodulators $(21,22)$. Ironically, now more than two decades after the eradication of smallpox, products of related poxviruses hold substantial promise for the treatment of human disease.

\footnotetext{
1. Kunkel, S.L. 1999. Through the looking glass: the diverse in vivo activities of chemokines. J. Clin. Invest. 104:1333-1334.

2. Liu, L., et al. 2000. The viral anti-inflammatory chemokine-binding protein M-T7 reduces intimal hyperplasia after vascular injury. J. Clin. Invest. 105:1613-1621

3. Damon, I., Murphy, P.M., and Moss, B. 1998.
}

Broad spectrum chemokine antagonistic activity of a human poxvirus chemokine homolog. Proc. Natl. Acad. Sci. USA. 95:6403-6407.

4. Bodaghi, B., et al. 1998. Chemokine sequestration by viral chemoreceptors as a novel viral escape strategy: withdrawal of chemokines from the environment of cytomegalovirus-infected cells. $J$. Exp. Med. 188:855-866.

5. Parry, B.C., et al. 2000. A broad spectrum secreted chemokine binding protein encoded by a herpesvirus. J. Exp. Med. 191:573-578.

6. van Berkel, $V$., et al. 2000. Identification of a gammaherpesvirus-selective chemokine binding protein that inhibits chemokine action. J. Virol. In press.

7. Bais, C., et al. 1998. G-protein-coupled receptor of Kaposi's sarcoma-associated herpesvirus is a viral oncogene and angiogenesis activator. Nature. 391:86-89.

8. Saederup, N., Lin, Y.C., Dairaghi, D.J., Schall, T.J., and Mocarski, E.S. 1999. Cytomegalovirusencoded beta chemokine promotes monocyteassociated viremia in the host. Proc. Natl. Acad. Sci. USA. 96:10881-10886.

9. Spriggs, M.K. 1996. One step ahead of the game: viral immunomodulatory molecules. Annu. Rev. Immunol. 14:101-130.

10. Lalani, A.S., et al. 1997. The purified myxoma virus gamma interferon receptor homolog M-T7 interacts with the heparin-binding domains of chemokines. J. Virol. 71:4356-4363.

11. Cook, D.N., et al. 1995. Requirement of MIP-1 alpha for an inflammatory response to viral infection. Science. 269:1583-1585.

12. Salazar-Mather, T.P., Orange, J.S., and Biron, C.A. 1998. Early murine cytomegalovirus (MCMV) infection induces liver natural killer (NK) cell inflammation and protection through macrophage inflammatory protein 1alpha (MIP-1alpha)dependent pathways. J. Exp. Med. 187:1-14.

13. Mossman, K., et al. 1996. Myxoma virus M-T7, a secreted homolog of the interferon-gamma receptor, is a critical virulence factor for the development of myxomatosis in European rabbits. Virology. 215:17-30.

14. Murphy, P.M., et al. 2000. International union of pharmacology. XXII. Nomenclature for chemokine receptors. Pharmacol. Rev. 52:145-176.

15. Berger, E.A., Murphy, P.M., and Farber, J.M. 1999. Chemokine receptors as HIV-1 coreceptors: roles in viral entry, tropism and disease. Annu. Rev Immunol. 17:657-700.

16. Gosling, J., et al. 1999. MCP-1 deficiency reduces susceptibility to atherosclerosis in mice that overexpress human apolipoprotein B. J. Clin. Invest. 103:773-778.

17. Boring, L., Gosling, J., Cleary, M., and Charo, I.F. 1998. Decreased lesion formation in CCR2-/mice reveals a role for chemokines in the initiation of atherosclerosis. Nature. 394:894-897.

18. Lucas, A., et al. 1996. Virus-encoded serine proteinase inhibitor SERP-1 inhibits atherosclerotic plaque development after balloon angioplasty. Circulation. 94:2890-2900.

19. Miller, L.W., et al. 2000. Inhibition of transplant vasculopathy in a rat aortic allograft model after infusion of anti-inflammatory viral serpin. Circu lation. 101:1598-1605.

20. Maksymowych, W.P., et al. 1996. Amelioration of antigen induced arthritis in rabbits treated with a secreted viral serine proteinase inhibitor. $J$. Rheumatol. 23:878-882.

21. Lucas, A., and McFadden, G. 1999. Harvesting viral proteins. Can. Med. Assoc. J. 161:1134.

22. Lalani, A.S., et al. 1999. Role of myxoma virus soluble CC-chemokine inhibitor glycoprotein, MT1, during myxoma virus pathogenesis. Virology. 256:233-245. 